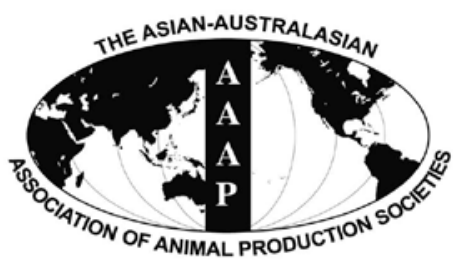

Asian-Aust. J. Anim. Sci.

Vol. 25, No. 1: 44 - 51

January 2012

www.ajas.info

http://dx.doi.org/10.5713/ajas.2011.11305

\title{
Regulation of S100G Expression in the Uterine Endometrium during Early Pregnancy in Pigs
}

\author{
Yohan Choi, Heewon Seo, Jangsoo Shim, Mingoo Kim and Hakhyun Ka* \\ Division of Biological Science and Technology, IPAID and Institute of Biomaterials, \\ Yonsei University, Wonju, 220-710, Korea
}

\begin{abstract}
Calcium ions play an important role in the establishment and maintenance of pregnancy, but molecular and cellular regulatory mechanisms of calcium ion action in the uterine endometrium are not fully understood in pigs. Previously, we have shown that calcium regulatory molecules, transient receptor potential vanilloid type 5 (TRPV6) and calbindin-D9k (S100G), are expressed in the uterine endometrium during the estrous cycle and pregnancy in a pregnancy status- and stage-specific manner, and that estrogen of conceptus origin increases endometrial TRPV6 expression. However, regulation of S100G expression in the uterine endometrium and conceptus expression of $S 100 G$ has been not determined during early pregnancy. Thus, we investigated regulation of S100G expression by estrogen and interleukin-1 $\beta$ (IL1B) in the uterine endometrium and conceptus expression of S100G during early pregnancy in pigs. We obtained uterine endometrial tissues from day (D) 12 of the estrous cycle and treated with combinations of steroid hormones, estradiol-17 $\left(\mathrm{E}_{2}\right)$ and progesterone $\left(\mathrm{P}_{4}\right)$, and increasing doses of IL1B. Real-time RT-PCR analysis showed that $\mathrm{E}_{2}$ and IL1B increased $S 100 G$ mRNA levels in the uterine endometrium, and conceptuses expressed S100G mRNA during early pregnancy, as determined by RT-PCR analysis. To determine if endometrial expression of S100G mRNA during the implantation period was affected by the somatic cell nuclear transfer (SCNT) procedure, we compared S100G mRNA levels in the uterine endometrium from gilts with SCNT-derived conceptuses with those from gilts with conceptuses derived from natural mating on D12 of pregnancy. Real-time RT-PCR analysis showed that levels of S100G mRNA in the uterine endometrium from gilts carrying SCNT-derived conceptuses was significantly lower than those from gilts carrying conceptuses derived from natural mating. These results showed that S100G expression in the uterine endometrium was regulated by estrogen and IL1B of conceptus origin, and affected by the SCNT procedure during early pregnancy. These suggest that conceptus signals regulate S100G, an intracellular calcium transport protein, for the establishment of pregnancy in pigs. (Key Words : Pig, Uterus, S100G, SCNT, Calcium)
\end{abstract}

\section{INTRODUCTION}

Calcium ion mediates complex intracellular signaling cascades as an intracellular secondary messenger at the cellular level (Clapham, 2007), and it is also essential for various physiological processes including bone formation, muscle contraction, milk formation, and neuron excitability (Brommage, 1989). Increasing evidence has suggested that calcium ions are involved in embryo implantation. Calcium entry into endometrial epithelial cells increases when endometrial cells bind to trophoblastic cells in human (Tinel et al., 2000). Binding of extracellular matrix (ECM) proteins with arginine-glycine-aspartic acid (RGD) sequence to integrins, which is an essential process in

\footnotetext{
* Corresponding Author : H. Ka. Tel: +82-33-760-2369, Fax: +82-33-760-2186, E-mail: hka@yonsei.ac.kr Received August 30, 2011; Accepted November 13, 2011
}

trophectoderm cell attachment to maternal endometrium, requires calcium ions (Somogyi et al., 1994), and activation of integrin $\beta 1$ and integrin $\beta 2$ by exposing their ligands causes extracellular calcium influx into the cell (Schwartz, 1993).

It is well studied in small intestine and kidney that the maintenance of cellular calcium ion balance is controlled by three steps of the transcellular calcium transport system, including several calcium regulatory molecules (Hoenderop et al., 2002). The first step of transcellular calcium transport is the influx of extracellular calcium ion into the epithelial cells by transient receptor potential vanilloid type 5 (TRPV5) and 6 (TRPV6). Next, intracellular calcium ions are transported by calcium transport proteins, calbindinD9k (S100G) and calbindin-D28k (CALB1), to the basolateral side of epithelial cells. Subsequently, intracellular calcium ions are extruded to outside of 
epithelial cells by sodium/calcium exchanger 1 (SLC8A1) and plasma membrane calcium ATPase 1 (ATP2B1).

Expression of the calcium regulatory molecules in the uterine endometrium has been reported in several species. TRPV6, a calcium ion channel, is expressed in the uterine endometrium during the estrous cycle and pregnancy in rats and mice (Kim et al., 2006; Lee and Jeung, 2007), and during the menstrual cycle in humans (Yang et al., 2011). S100G, an intracellular calcium ion transport protein, is expressed in the uterine endometrium during the estrous cycle and pregnancy in mice (Warembourg et al., 1987), rats (Tatsumi et al., 1999) and pigs (Krisinger et al., 1995). ATP2B1, a calcium ion extrusion-related molecule, is present in the uterine endometrium in rats and humans (Kim et al., 2006; Yang et al., 2011). In pigs, we have shown that uterine endometrial TRPV6 and S100G are expressed in the uterine endometrium in a pregnancy status- and stagespecific manner during the estrous cycle and pregnancy in pigs (Choi et al., 2009). These findings suggest that calcium ion concentrations in the uterine endometrium are controlled by these calcium regulatory molecules during the estrous cycle and pregnancy. However, regulatory mechanisms for expression of these endometrial calcium regulatory molecules are not well studied in pigs.

During the implantation period in pigs, elongating conceptuses (embryos/fetuses and associated extraembryonic membranes) secrete estrogen and cytokines such as interleukin-1 $\beta$ (IL1B) (Jaeger et al., 2001; Ross et al., 2003). Estrogen plays a key role in redirection of endometrial PGF2 $\alpha$ secretion from the uterine vasculature to the uterine lumen to maintain corpus luteum (CL) in the ovary (luteotrophic), thereby secretion of progesterone from CL is sustained throughout pregnancy. Estrogen also regulates expression of many uterine endometrial genes, including fibroblast growth factor 7 (FGF7), lysophosphatidic acid receptor 3 (LPAR3), and secreted phosphoprotein 1 (SPP1) during the implantation period (Jaeger et al., 2001). In our previous study, it has been shown that endometrial TRPV6 expression is increased by estrogen during the implantation period (Choi et al., 2009), but effect of estrogen on endometrial $S 100 G$ expression has been not determined. In addition to estrogen, conceptus produces IL1B into uterine lumen at the time of implantation in pigs (Jaeger et al., 2001; Ross et al., 2003). It has been reported that IL1B activates microsomal prostaglandin $\mathrm{E}_{2}$ synthase-1 (PTGES) in uterine tissues to stimulate synthesis of $\mathrm{PGE}_{2}$ for inhibition of luteolysis in the porcine uterus (Franczak et al., 2010), but effect of IL1B on endometrial gene expression is not much understood.

Somatic cell nuclear transfer (SCNT) technique to generate cloned animals for basic and applied research is a powerful tool, but the problem of low efficiency to produce viable cloned animals is yet to be solved. The causes of low efficiency of SCNT technique include incomplete nuclear reprogramming of the donor nucleus (Humphreys et al., 2001; Farin et al., 2006), abnormal extra-embryonic tissue formation (Chae et al., 2006; Jouneau et al., 2006; Kim et al., 2009), and the inappropriate uterine responsiveness to the developing conceptuses (Kim et al., 2005; Ka et al., 2008). Abnormal expression of genes involved in steroidogenesis, uterine tissue remodeling, and immune function has been reported in uterine tissues from gilts with SCNT-derived conceptuses (Ka et al., 2008). However, there is not much information available for effect of SCNT procedure on expression of calcium regulatory molecules in the uterine endometrium from gilts with SCNT-derived conceptuses at the time of implantation in pigs.

Therefore, this study was to determine i) regulation of the uterine endometrial S100G expression by estrogen and IL1B during the implantation period; ii) expression of S100G in conceptuses during early pregnancy; and iii) expression of $S 100 G$ in the uterine endometrium from gilts with SCNT-derived conceptuses compared to that from gilts with conceptuses derived from natural mating on day (D) 12 of pregnancy.

\section{MATERIALS AND METHODS}

\section{Animals and tissue preparation}

All experimental procedures involving animals were conducted in accordance with the Guide for Care and Use of Research Animals in Teaching and Research and approved by the Institutional Animal Care and Use Committee of Yonsei University. Sexually mature crossbred female gilts (ages between 8 and 12 months) were assigned randomly to either cyclic or pregnant status and hysterectomized on either day (D) 12 of the estrous cycle or D12 and D15 of pregnancy ( $n=3$ gilts/d/status) after the animals were slaughtered. Pregnancy was confirmed by the presence of apparently normal conceptuses with filamentous morphology in uterine flushings from D12 and D15 of pregnancy. Oocyte collection, in vitro maturation, SCNT procedures and endometrial tissue sampling from gilts carrying embryos derived from SCNT on D12 of pregnancy were done as described previously (Ka et al., 2008; Kim et al., 2009). On D12 of pregnancy, uterine endometrial tissues were obtained from four gilts that carried SCNT-derived conceptuses and three gilts with conceptuses resulting from natural mating. Endometrium samples, dissected free from myometrium, were collected from the middle portion of each uterine horn of each gilt. For RNA extraction, endometrial tissues were snap-frozen in liquid nitrogen and stored at $-80^{\circ} \mathrm{C}$.

\section{Explant culture}

Endometrium was dissected from the myometrium and 
placed into warm phenol red-free DMEM/F-12 culture medium (Sigma, St. Louis, MO, USA) containing penicillin $\mathrm{G}(100 \mathrm{IU} / \mathrm{ml})$ and streptomycin $(0.1 \mathrm{mg} / \mathrm{ml})$ as described previously (Ka et al., 2001), with some modifications. The endometrium was minced with scalpel blades into small pieces (2 to $3 \mathrm{~mm}^{3}$ ), and aliquots of $500 \mathrm{mg}$ were placed into T25 flasks with serum-free modified DMEM/F-12 containing $10 \mu \mathrm{g} / \mathrm{ml}$ insulin (Sigma, catalog no. I5500), 10 $\mathrm{ng} / \mathrm{ml}$ transferrin (Sigma, catalog no. T1428), and $10 \mathrm{ng} / \mathrm{ml}$ hydrocortisone (Sigma, catalog no. H0396). Endometrial explants were cultured immediately after mincing in progesterone $\left(\mathrm{P}_{4} ; 3 \mathrm{ng} / \mathrm{ml}\right.$; Sigma, catalog no. $\left.\mathrm{P} 0130\right), \mathrm{P}_{4}{ }^{+}$ estradiol-17ß ( $\mathrm{E}_{2} ; 50 \mathrm{ng} / \mathrm{ml}$; Sigma, catalog no. E8875), $\mathrm{P}_{4}$ $+\mathrm{E}_{2}+\mathrm{ICI} 182,780$ (ICI; an estrogen receptor antagonist; 100 $\mathrm{ng} / \mathrm{ml}$; Tocris, Ballwin, MO, USA), or $\mathrm{E}_{2}+\mathrm{P}_{4}+\mathrm{RU} 486$ (a progesterone receptor antagonist; $30 \mathrm{ng} / \mathrm{ml}$; Sigma, catalog no. M8046), for $24 \mathrm{~h}$ with rocking in an atmosphere of 5\% carbon dioxide in air at $37^{\circ} \mathrm{C}$. To determine the effects of cytokines on S100G expression, explant tissues were treated with $0,1,10,100 \mathrm{ng} / \mathrm{ml}$ IL1B (catalog number I9401; Sigma) in the presence of both $\mathrm{E}_{2}(50 \mathrm{ng} / \mathrm{ml})$ and $\mathrm{P}_{4}$ (3 $\mathrm{ng} / \mathrm{ml}$ ) at $37^{\circ} \mathrm{C}$ for $24 \mathrm{~h}$. Explant tissues were then harvested and total RNA was extracted for real-time RT-PCR analysis of S100G mRNA levels. These experiments were conducted using endometrium from three individual gilts. Treatments were performed in triplicate on tissues obtained from each gilt.

\section{Total RNA extraction, cloning of porcine $S 100 G$ and RT- PCR}

Total RNA was extracted from endometrial tissues and conceptuses from D12 and 15 of pregnancy using TRIzol reagent (Invitrogen Life Technology, Carlsbad, CA, USA) according to the manufacturer's recommendations. The quantity of RNA was assessed spectrophotometrically, and the integrity of the RNA was examined by gel electrophoresis using $1 \%$ agarose gels.

Two micrograms of total RNA were treated with DNase I (Promega, Madison, WI) and reverse transcribed using SuperScript II Reverse Transcriptase (Invitrogen) to obtain cDNA. The cDNA templates were then diluted 1:4 with sterile water and amplified by PCR using Taq polymerase (Takara Bio, Shiga, Japan) and specific primers (forward, 5'-TCC TGC AGA ACT GAA GAG CA-3'; reverse, 5'GCA GAG ACA TGG GTG GTT TT-3') based on mRNA sequences of porcine S100G (GenBank accession no. NM_214140). PCR conditions were 40 cycles of $94^{\circ} \mathrm{C}$ for $30 \mathrm{~s}, 60^{\circ} \mathrm{C}$ for $30 \mathrm{~s}$, and $72^{\circ} \mathrm{C}$ for $1 \mathrm{~min}$. PCR products with the expected size of $302 \mathrm{bp}$ were separated on $2 \%$ agarose gels and visualized by ethidium bromide staining. The identity of each amplified PCR product was verified by sequence analysis after cloning into the pCRII vector (Invitrogen).

\section{Real-time quantitative RT-PCR}

To analyze levels of S100G mRNAs in the uterine endometrium, real-time RT-PCR was performed using the Applied Biosystems StepOnePlus System (Applied Biosystems, Foster City, CA, USA) using the SYBR Green method. Complementary DNAs were synthesized from $3 \mu \mathrm{g}$ of total RNA isolated from different uterine endometrial tissues, and newly synthesized cDNAs (total volume of 21 $\mu \mathrm{l})$ were used for PCR. To maximize efficiency, specific primers based on porcine S100G (GenBank accession No. NM 214140, forward, 5'-TGA AAG GTC CGA GAA CCC TAG ATG-3'; reverse, 5'-TCC TTA AAA TGG GAC TGT TGC GTG-3') and porcine ribosomal protein L7 (RPL7) (GenBank accession No. NM_0011132176, Forward: 5' AAG CCA AGC ACT ATC ACA AGG AAT ACA - 3'; Reverse: 5' - TGC AAC ACC TTT CTG ACC TTT GG 3') were designed to amplify cDNA of less than $200 \mathrm{bp}$. Final reaction volume was $20 \mu \mathrm{l}$ including $2 \mu \mathrm{l}$ of cDNA, $10 \mu \mathrm{l}$ of $2 \mathrm{X}$ premix, $2 \mu \mathrm{l}$ of each primer, $0.4 \mu \mathrm{l}$ of ROX and $3.6 \mu \mathrm{l}$ of DEPC-treated ddH2O. PCR conditions were $95^{\circ} \mathrm{C}$ for $10 \mathrm{~min}$ followed by 40 cycles of $95^{\circ} \mathrm{C}$ for $30 \mathrm{~s}, 60^{\circ} \mathrm{C}$ for $30 \mathrm{~s}$, and $72^{\circ} \mathrm{C}$ for $30 \mathrm{~s}$. Data were analyzed using Applied Biosystems software. The results were reported as the expression relative to the level detected in control group after normalization of the transcript amount to the endogenous RPL7 levels by the $2^{-\Delta \Delta \mathrm{CT}}$ method (Livak and Schmittgen, 2001).

\section{Statistical analyses}

Data from real-time RT-PCR analysis for S100G mRNA levels were subjected to least squares ANOVA using the General Linear Models procedures of SAS (Cary, NC, USA). To evaluate the effect of steroid hormones on S100G mRNA levels, the model included treatment and animal as sources of variation. Preplanned contrasts $\left(\mathrm{P}_{4}\right.$ vs. $\mathrm{P}_{4}+\mathrm{E}_{2} ; \mathrm{P}_{4}$ vs. $\mathrm{P}_{4}+\mathrm{E}_{2}+\mathrm{RU} 486 ; \mathrm{P}_{4}+\mathrm{E}_{2}$ vs. $\mathrm{P}_{4}+\mathrm{E}_{2}+\mathrm{ICI}$; and $\mathrm{P}_{4}+\mathrm{E}_{2}$ vs. $\mathrm{P}_{4}+\mathrm{E}_{2}+\mathrm{RU} 486$ ) were used to test for effects of treatments in the explant cultures. Data are presented as least squares means with standard error (SE). Data from IL1B doseresponse studies on $S 100 G$ expression were analyzed by least squares regression analysis. Data from real-time RTPCR for S100G mRNA levels in the endometrial tissues from uteri with SCNT-derived and non-NT conceptuses were subjected to the Student's $t$ test procedure of SAS, and are presented as means with SE.

\section{RESULTS}

\section{Regulation of $S 100 G$ expression by steroid hormones in the uterine endometrium pregnancy in pigs}

To determine whether endometrial S100G expression was affected by steroid hormones and during the implantation period in pigs, the uterine endometrial tissue 
explants from gilts on D12 of the estrous cycle were treated with $\mathrm{P}_{4}, \mathrm{P}_{4}+\mathrm{E}_{2}, \mathrm{P}_{4}+\mathrm{E}_{2}+\mathrm{ICI}$, or $\mathrm{P}_{4}+\mathrm{E}_{2}+\mathrm{RU} 486$. As shown in Figure 1, S100G mRNA levels in the uterine endometrial explant tissues were increased by the addition of $E_{2}$ in the presence of $\mathrm{P}_{4}$ compared with those treated with $\mathrm{P}_{4}$ alone $\left(\mathrm{P}_{4}\right.$ vs. $\left.\mathrm{P}_{4}+\mathrm{E}_{2} ; \mathrm{p}<0.05\right)$. Addition of RU486, a progesterone receptor (PGR) antagonist, in the presence of $\mathrm{P}_{4}$ and $\mathrm{E}_{2}$ did not affect levels of $S 100 G$ mRNA expression $\left(\mathrm{P}_{4}+\mathrm{E}_{2}\right.$ vs. $\mathrm{P}_{4}+\mathrm{E}_{2}+\mathrm{RU} 486$; $\mathrm{p}>0.05$ ), but treatment of ICI, an estrogen receptor (ESR1) antagonist, in the presence of $\mathrm{P}_{4}$ and $\mathrm{E}_{2}$ attenuated the effect of $E_{2}$ on increased endometrial S100G expression $\left(\mathrm{P}_{4}+\mathrm{E}_{2}\right.$ vs. $\left.\mathrm{P}_{4}+\mathrm{E}_{2}+\mathrm{ICI} ; \mathrm{p}<0.05\right)$.

\section{Effect of IL1B on S100G expression in the uterine} endometrium on in pigs

To determine the effect of IL1B, which is secreted by elongating conceptuses during the implantation period in pigs (Jaeger et al., 2001; Ross et al., 2003), on S100G expression, we performed real-time RT-PCR analysis using the uterine endometrial explant tissues obtained on D12 of the estrous cycle and treated with $0,1,10$, or $100 \mathrm{ng} / \mathrm{ml}$ IL1B in the presence of both $\mathrm{E}_{2}$ and $\mathrm{P}_{4}$. As shown in Figure 2 , increasing doses of IL1B induced S100G expression in the uterine endometrium (linear effect of dose, $\mathrm{p}<0.05$ ).

\section{Expression of S100G mRNA in porcine conceptuses during early pregnancy}

To determine if S100G was expressed by conceptus tissues during early pregnancy, conceptuses were collected from gilts on D12 and D15 of pregnancy. As shown in

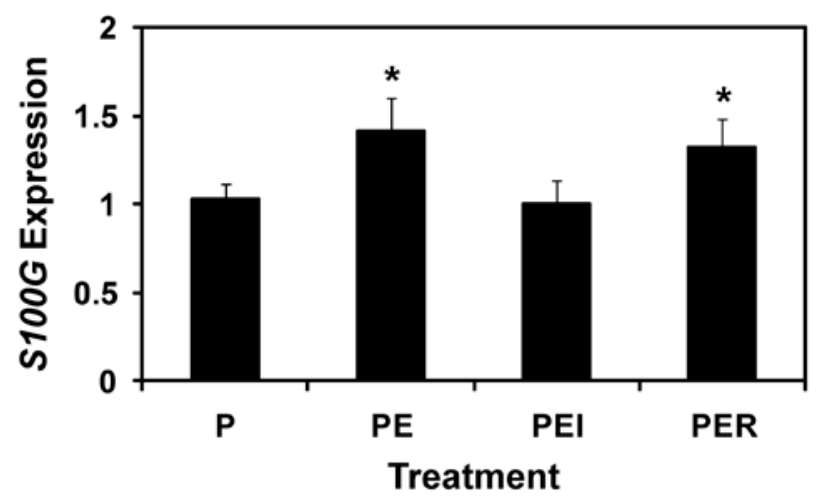

Figure 1. Effects of steroid hormones on endometrial S100G by real-time RT-PCR analysis. Uterine endometrial explant tissues from gilts on $\mathrm{D} 12$ of the estrous cycle were treated with $\mathrm{P}_{4}(\mathrm{P}$ alone), $\mathrm{P}_{4}+\mathrm{E}_{2}$ (E) (PE), $\mathrm{P}_{4}+\mathrm{E}_{2}+\mathrm{ICI}$ (I; an estrogen receptor antagonist) (PEI), or $\mathrm{P}_{4}+\mathrm{E}_{2}+\mathrm{RU} 486$ (R; a progesterone receptor antagonist) (PER), and levels of $S 100 G$ mRNA were analyzed by real-time RT-PCR. Abundance of mRNA expression is relative to that for S100G mRNA in the control group of endometrial explants ( $\mathrm{P}$ alone) after normalization of transcript amounts to $R P L 7$ mRNA. Data are presented as least squares means with standard error. Asterisk $\left(^{*}\right), \mathrm{p}<0.05$.

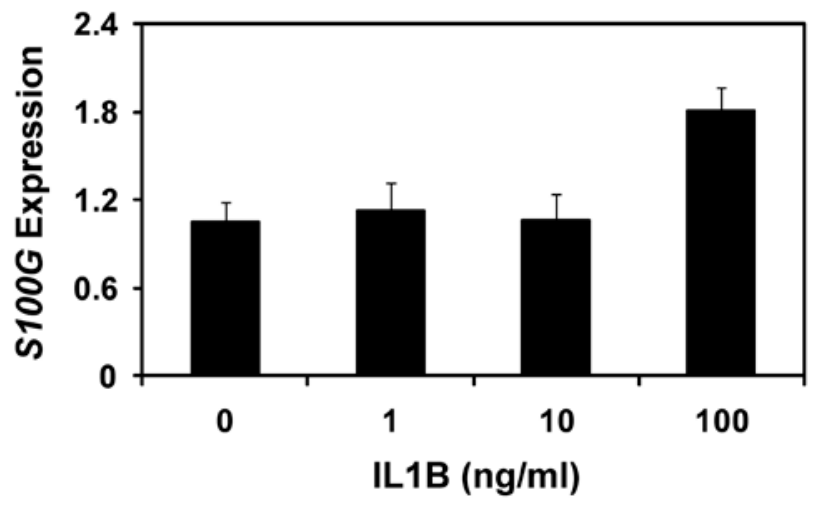

Figure 2. Effect of IL1B on endometrial S100G expression by real-time RT-PCR analysis. Uterine endometrial explant tissues from gilts on $\mathrm{D} 12$ of the estrous cycle were treated with increasing doses of IL1B in the presence of both $\mathrm{P}_{4}$ and $\mathrm{E}_{2}$ at $37^{\circ} \mathrm{C}$ for $24 \mathrm{~h}$, and levels of $S 100 G$ mRNA were analyzed by real-time RT-PCR. Abundance of mRNAs is presented as expression relative to that for mRNAs in the control group of endometrial explants after normalization of transcript amounts to RPL7 mRNA. Data are presented as least squares means with standard error.

Figure 3, S100G mRNA was detected in conceptuses on D12 and D15 of pregnancy in pigs.

Analysis of S100G mRNA levels in the uterine endometrium carrying SCNT-derived conceptuses or conceptuses from natural mating on D12 of pregnancy in pigs.

It was of interest to determine effect of SCNT procedure on the uterine endometrial S100G expression during early pregnancy. We obtained uterine endometrial tissues from

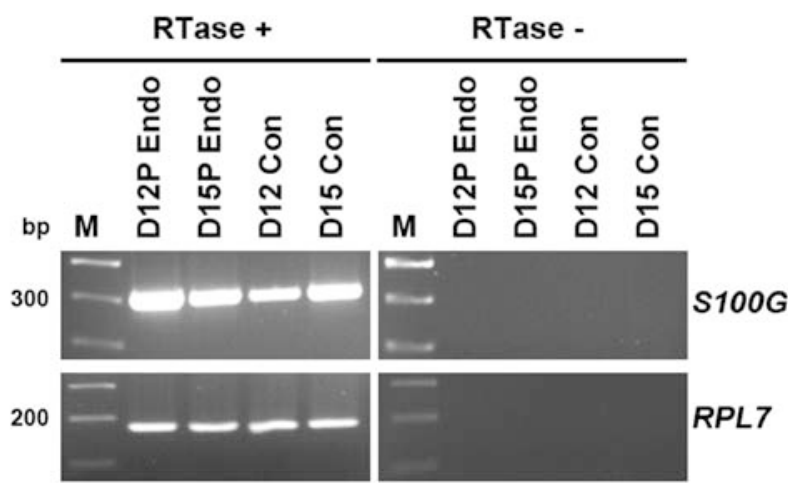

Figure 3. Expression of $S 100 G$ in porcine conceptuses during early pregnancy in pigs by RT-PCR analysis. Conceptus and endometrial cDNAs were synthesized from total RNAs of conceptuses and endometrial tissue samples (positive controls) from D12 and D15 of pregnancy. RPL7 cDNA was used as a loading control. S100G mRNA was detected in conceptuses on D12 and D15 of pregnancy. RTase +/-, with (+) or without (-) reverse transcriptase; $\mathrm{M}$, molecular marker; D12 Endo, endometrium from D12 of pregnancy; D15 Endo, endometrium from D15 of pregnancy; D12 Con, D12 conceptus; D15 Con, D15 conceptus. 
gilts with SCNT-derived conceptuses and gilts with conceptuses derived from natural mating on D12 of pregnancy, and analyzed $S 100 G$ mRNA levels by real-time RT-PCR. Levels of S100G mRNA in the uterine endometrium of gilts with SCNT-derived conceptuses were significantly lower than those of gilts with conceptuses derived from natural mating $(\mathrm{p}<0.05$; Figure 4$)$.

\section{DISCUSSION}

In this study in pigs we determined that i) S100G expression was increased by estrogen and IL1B of conceptus origin in the uterine endometrium during the implantation period; ii) $S 100 G$ mRNA was expressed in conceptuses during early pregnancy; and iii) endometrial S100G expression was decreased in the uterus from gilts with SCNT-derived conceptuses during the implantation period.

Receptivity to conceptus implantation in the uterus during early pregnancy in pigs is regulated mainly by actions of steroid hormones, $\mathrm{P}_{4}$ and $\mathrm{E}_{2}$, which change expression of many uterine endometrial genes (Bazer et al., 2010). On D12 of pregnancy, elongating porcine conceptuses secrete estrogen, a signal for the maternal recognition of pregnancy, to stimulate anti-luteolytic mechanisms during this period for establishment and maintenance of pregnancy (Bazer and Thatcher, 1977). Estrogen also affect expression of many uterine endometrial genes such as FGF7 (Ka et al., 2001), SPP1 (White et al., 2005), LPAR3 (Seo et al., 2008), signal transducers and activator of transcription 1 (STAT1) (Joyce et al., 2007), and stanniocalcin 1 (STC1) (Song et al., 2009). Previously, we have shown that TRPV6 is expressed in the uterine

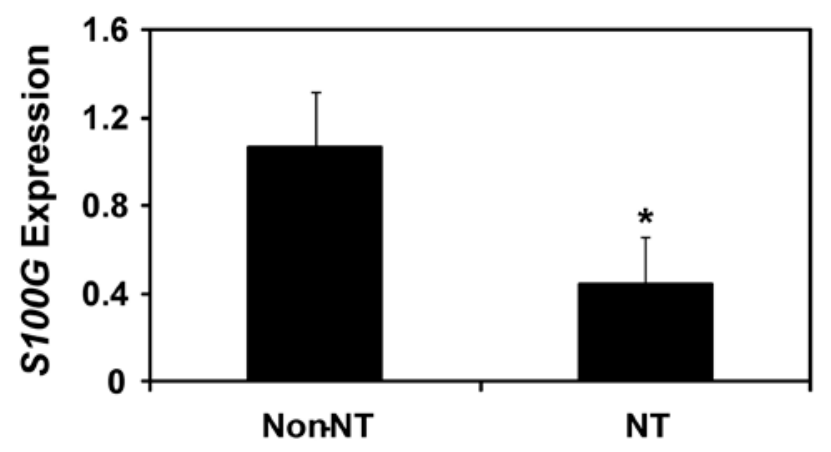

Figure 4. Analysis of $S 100 G$ mRNA levels in the uterine endometrium from gilts with conceptuses derived from natural mating (non-NT) and those from gilts with SCNT-derived conceptuses (NT) on D12 of pregnancy using real-time RT-PCR analysis. Abundance of mRNA is presented as expression relative to that for $S 100 G$ mRNA in uterine endometria from gilts with non-NT conceptuses after normalization of transcript amounts to RPL7 mRNA. Levels of endometrial S100G mRNA expression of uteri from gilts with SCNT-derived conceptuses were significantly lower than those from gilts with non-NT conceptuses $(\mathrm{p}<0.05)$. endometrium during early pregnancy and up-regulated by $\mathrm{E}_{2}$ (Choi et al., 2009). We have also shown that S100G is expressed in the uterine endometrium during pregnancy in a biphasic expression pattern with higher levels at the time of implantation and term pregnancy (Choi et al., 2009). However, regulating mechanism for endometrial S100G expression has not been determined. Thus, we hypothesized that estrogen of conceptus origin affects expression of S100G in the uterine endometrium during early pregnancy. Indeed, results of this study showed that $E_{2}$ increased expression of $S 100 G$ in the uterine endometrium, indicating that $E_{2}$ affects expression of calcium regulatory molecules of both TRPV6 and S100G in the endometrium in pigs. In addition, $E_{2}$-induced increase of $S 100 G$ expression was ESR1-mediated, because S100G expression was decreased when ESR1 action was blocked by the addition of ESR1 antagonist. In this study, $\mathrm{P}_{4}$ did not have any effect on S100G expression when $\mathrm{P}_{4}$ action was blocked by treatment of RU486, a PGR antagonist. However, it is likely that $\mathrm{P}_{4}$ is prerequisite for endometrial S100G expression, because $\mathrm{P}_{4}$ down-regulates PGR expression in the endometrial luminal and glandular epithelium during the implantation period (Geisert et al., 1994). The priming effect of $\mathrm{P}_{4}$ on endometrial gene expression has been evidenced in FGF7 expression in pigs (Ka et al., 2007). In ovariectomized gilts, $\mathrm{P}_{4}$ was permissive to FGF7 expression by down-regulating PGR in luminal epithelium, and FGF7 expression by estrogen was increased when $\mathrm{P}_{4}$ was present, or PGR was blocked (Ka et al., 2007).

In pigs, trophoblast cells of elongating conceptuses also synthesize and secrete some cytokines such as IL1B during the implantation period (Tuo et al., 1996; Jaeger et al., 2001; Ross et al., 2003). It has been suggested that IL1B secreted from conceptuses is involved in communication between the maternal endometrium and the conceptus, and changes in many endometrial gene expression (Jaeger et al., 2001; Ross et al., 2003). Thus, we postulated that IL1B of conceptus origin might affect $S 100 G$ expression in the endometrium during the implantation period. Results of this study showed that IL1B as well as $\mathrm{E}_{2}$ increased S100G expression. Since endometrial genes regulated by IL1B in the porcine uterus during the implantation period, are not much known, information of S100G being an IL1Bregulated gene would be valuable for understanding the function of IL1B in the uterine endometrium during early pregnancy. Beside IL1B, two types of interferons (IFNs), IFNG and IFND, are produced by conceptuses and secreted into uterine lumen during early pregnancy in pigs (Lefèvre et al., 1990; La Bonnardière et al., 1991). Although synthesis and secretion of IFNs by conceptuses occurs between D12 and D20 of pregnancy, the peak of synthesis and secretion of IFNs is observed on D15 to 16 of pregnancy in pigs so that effects of IFNs on endometrial 
S100G expression were not determined in the present study.

During pregnancy, S100G is expressed in the placental trophoblast in humans and mice (Glazier et al., 1995; Shamley et al., 1996; Belkacemi et al., 2004) and intraplacentomal trophoblast of sheep and cow (Morgan et al., 1997; Nikitenko et al., 1998), suggesting that placental S100G participates in calcium transport for supplying calcium to developing embryos during pregnancy. Because S100G expression has not been determined in porcine conceptus during early pregnancy, we examined whether S100G was expressed in conceptuses from D12 and D15 of pregnancy. Results of the study showed that porcine conceptus during early pregnancy expressed S100G, suggesting that calcium absorption and transport system may be important for early embryo development in pigs, since TRPV6 is also expressed in conceptus trophectoderm during early pregnancy.

Somatic cell nuclear transfer (SCNT) technique to generate many cloned animals contributed significantly to basic and applied biological research, but efficiency to acquire viable offspring is still extremely low (Campbell et al., 2005). However, the cause of the low efficiency has not been completely understood. Our previous study has shown that uterine responsiveness to SCNT-derived conceptus is impaired during mid- to term pregnancy in pigs (Ka et al., 2008; Kim et al., 2009). Thus, we examined whether endometrial gene expression was changed in the uterus with SCNT-derived conceptus at the time of implantation. In this study, levels of $S 100 G$ expression in the uterine endometrium from gilts with SCNT-derived conceptuses were significantly lower than those with conceptuses generated by natural mating on D12 of pregnancy. We have observed that conceptus secretion of $\mathrm{E}_{2}$ and IL1B is greatly reduced in the uterus with SCNT-derived conceptuses on D12 of pregnancy (Seo and Ka, unpublished data). Therefore, lowered levels of S100G expression in the endometrium from gilts with SCNT-derived conceptuses may be due to decreased levels of $E_{2}$ and IL1B from SCNTderived conceptuses. These suggest that inappropriate maternal-conceptus interactions such as aberrant expression of calcium regulatory molecules may cause embryonic mortality in pregnancy of SCNT-derived conceptuses.

In conclusion, expression of endometrial S100G, involved in intracellular calcium transport, was regulated by estrogen and IL1B during the implantation period, detected in conceptuses during early pregnancy, and affected by the SCNT procedure on D12 of pregnancy. These results suggest that endometrial calcium ion concentration in the uterus may be regulated by conceptus signals at the time of implantation, and that inappropriate conceptus-endometrial interaction may cause decreased levels of S100G expression in the endometrium with SCNT-derived conceptus during the implantation period in pigs. These results provide important insight into regulation of calcium ion concentration and calcium regulatory molecules at the maternal-conceptus interface at the time of conceptus implantation in pigs.

\section{ACKNOWLEDGEMENTS}

This study was supported by the BioGreen 21 Program (\#PJ007997), Rural Development Administration, and by the National Research Foundation (NRF-2010-0012304) funded by the Korean Government, Republic of Korea.

\section{REFERENCES}

Bazer, F. W. and W. W. Thatcher. 1977. Theory of maternal recognition of pregnancy in swine based on estrogen controlled endocrine versus exocrine secretion of prostaglandin F2alpha by the uterine endometrium. Prostaglandins 14(2):397-400.

Bazer, F. W., G. Wu, T. E. Spencer, G. A. Johnson, R. C. Burghardt and K. Bayless. 2010. Novel pathways for implantation and establishment and maintenance of pregnancy in mammals. Mol. Hum. Reprod. 16(3):135-152.

Belkacemi, L., G. Gariépy, C. Mounier, L. Simonea and J. Lafond. 2003. Calbindin-D9k (CaBP9k) localization and levels of expression in trophoblast cells from human term placenta. Cell. Tissue Res. 315(1):107-117.

Brommage, R. 1989. Measurement of calcium and phosphorus fluxes during lactation in the rat. J. Nutr. 119(3):428-438.

Campbell, K. H., R. Alberio, I. Choi, P. Fisher, R. D. Kelly, J. H. Lee and W. Maalouf. 2005. Cloning: eight years after dolly. Reprod. Domest. Anim. 40(4):256-268.

Chae, J. I., S. K. Cho, J. W. Seo, T. S. Yoon, K. S. Lee, J. H. Kim, K. K. Lee, Y. M. Han and K. Yu. 2006. Proteomic analysis of the extraembryonic tissue from cloned porcine embryos. Mol. Cell. Proteomics 5(9):1559-1566.

Choi, Y., H. Seo, M. Kim and H Ka. 2009. Dynamic expression of calcium-regulatory molecules, TRPV6 and S100G, in the uterine endometrium during pregnancy in pigs. Biol. Reprod. 81(6):1122-1130.

Clapham, D. E. 2007. Calcium signaling. Cell. 131(6):1047-1058.

Farin, P. W., J. A. Piedrahita and C. E. Farin. 2006. Errors in development of fetuses and placentas from in vitro-produced bovine embryos. Theriogenology 65(1):178-191.

Franczak, A., A. Zmijewska, B. Kurowicka, B. Wojciechowicz and G. Kotwica. 2010. Interleukin 1 $\beta$-induced synthesis and secretion of prostaglandin $E_{2}$ in the porcine uterus during various periods of pregnancy and the estrous cycle. J. Physiol. Pharmacol. 61(6):733-742.

Geisert, R. D., T. N. Pratt, F. W. Bazer, J. S. Mayes and G. H. Watson. 1994. Immunocytochemical localization and changes in endometrial progestin receptor protein during the porcine oestrous cycle and early pregnancy. Reprod. Fertil. Dev. 6(6):749-760.

Glazier, J. D., E. B. Mawer and C. P. Sibley. 1995. Calbindin-D9K gene expression in rat chorioallantoic placenta is not regulated by 1,25-dihydroxyvitamin D3. Pediatr. Res. 37(6):720-725. 
Hoenderop, J. G., B. Nilius and R. J. Bindels. 2002. Molecular mechanism of active Ca2+ reabsorption in the distal nephron. Annu. Rev. Physiol. 64:529-549.

Humpherys, D., K. Eggan, H. Akutsu, A. Friedman, K. Hochedlinger, R. Yanagimachi, E. S. Lander, T. R. Golub and R. Jaenisch. 2002. Abnormal gene expression in cloned mice derived from embryonic stem cell and cumulus cell nuclei. Proc. Natl. Acad. Sci. USA. 99(20):12889-12894.

Jaeger, L. A., G. A. Johnson, H. Ka, J. G. Garlow, R. C. Burghardt, T. E. Spencer and F. W. Bazer. 2001. Functional analysis of autocrine and paracrine signalling at the uterine-conceptus interface in pigs. Reprod. Suppl. 58:191-207.

Jouneau, A., Q. Zhou, A. Camus, V. Brochard, L. Maulny, J. Collignon and J. P. Renard. 2006. Developmental abnormalities of NT mouse embryos appear early after implantation. Development 133(8):1597-1607.

Joyce, M. M., R. C. Burghardt, R. D. Geisert, J. R. Burghardt, R. N. Hooper, J. W. Ross, M. D. Ashworth and G. A. Johnson. 2007. Pig conceptuses secrete estrogen and interferons to differentially regulate uterine STAT1 in a temporal and cell type-specific manner. Endocrinology 148(9):4420-4431.

Ka, H., H. Seo, M. Kim, S. Moon, H. Kim and C. K. Lee. 2008. Gene expression profiling of the uterus with embryos cloned by somatic cell nuclear transfer on day 30 of pregnancy. Anim. Reprod. Sci. 108(1-2):79-91.

Ka, H., L. A. Jaeger, G. A. Johnson, T. E. Spencer and F. W. Bazer. 2001. Keratinocyte growth factor is up-regulated by estrogen in the porcine uterine endometrium and functions in trophectoderm cell proliferation and differentiation. Endocrinology 142(6):2303-2310.

Ka, H., S. Al-Ramadan, D. W. Erikson, G. A. Johnson, R. C. Burghardt, T. E. Spencer, L. A. Jaeger and F. W. Bazer. 2007. Regulation of expression of fibroblast growth factor 7 in the pig uterus by progesterone and estradiol. Biol. Reprod. 77(1):172-180.

Kim, H. J., G. S. Lee, Y. K. Ji, K. C. Choi and E. B. Jeung. 2006. Differential expression of uterine calcium transporter 1 and plasma membrane $\mathrm{Ca}^{2+}$ ATPase $1 \mathrm{~b}$ during rat estrous cycle. Am. J. Physiol. Endocrinol. Metab. 291(2):E234-E241.

Kim, H. R., J. K. Kang, J. T. Yoon, H. H. Seong, J. K. Jung, H. M. Lee, C. Sik. Park and D. I. Jin. 2005. Protein profiles of bovine placenta derived from somatic cell nuclear transfer. Proteomics 5(16):4264-4273.

Kim, M., H. Seo, Y. Choi, W. Hwang, C. K. Lee and H. Ka. 2009. Aberrant expression of retinol-binding protein, osteopontin and fibroblast growth factor 7 in the porcine uterine endometrium of pregnant recipients carrying embryos produced by somatic cell nuclear transfer. Anim. Reprod. Sci. 112(1-2):172-181.

Krisinger, J., E. B. Jeung, R. C. Simmen and P. C. Leung. 1995. Porcine calbindin-D9k gene: expression in endometrium, myometrium, and placenta in the absence of a functional estrogen response element in intron A. Biol. Reprod. 52(1):115-123.

La Bonnardière, C., F. Martinat-Botte, M. Terqui, F. Lefe`vre, K. Zouari, J. Martal and F. W. Bazer. 1991. Production of two species of interferon by Large White and Meishan pig conceptuses during the peri-attachment period. J. Reprod. Fertil. 91(2):469-478.
Lee, G. S. and E. B. Jeung. 2007. Uterine TRPV6 expression during the estrous cycle and pregnancy in a mouse model. Am. J. Physiol. Endocrinol. Metab. 293(1):E132-E138.

Lefe vre, F., F. Martinat-Botte, M. Guillomot, K. Zouari, B. Charley and C. La Bonnardière. 1990. Interferon-gamma gene and protein are spontaneously expressed by the porcine trophoectoderm early in gestation. Eur. J. Immunol. 20(11):2485-2490.

Livak, K. J. and T. D. Schmittgen. 2001. Analysis of relative gene expression data using real-time quantitative PCR and the 2(Delta Delta C(T)) Method. Methods. 25(4):402-408.

Morgan, G., F. B. Wooding, A. D. Care and G. V. Jones. 1997. Genetic regulation of placental function: a quantitative in situ hybridization study of calcium binding protein (calbindin-D9k) and calcium ATPase mRNAs in sheep placenta. Placenta 18(2-3):211-218

Nikitenko, L., G. Morgan, S. I. Kolesnikov and F. B. Wooding. 1998. Immunocytochemical and In situ hybridization studies of the distribution of calbindin D9k in the bovine placenta throughout pregnancy. J. Histochem. Cytochem. 46(5):679688.

Ross, J. W., J. R. Malayer, J. W. Ritchey and R. D. Geisert. 2003. Characterization of the interleukin-1beta system during porcine trophoblastic elongation and early placental attachment. Biol. Reprod. 69(4):1251-1259.

Schwartz, M. A. 1993. Spreading of human endothelial cells on fibronectin or vitronectin triggers elevation of intracellular free calcium. J. Cell Biol. 120(4):1003-1010.

Seo, H., M. Kim, Y. Choi, C. K. Lee and H. Ka. 2008. Analysis of lysophosphatidic acid (LPA) receptor and LPA-induced endometrial prostaglandin-endoperoxide synthase 2 expression in the porcine uterus. Endocrinology 149(12):6166-6175.

Shamley, D. R., G. Veale, J. M. Pettifor and R. Buffenstein. 1996. Trophoblastic giant cells of the mouse placenta contain calbindin-D9k but not the vitamin D receptor. J. Endocrinol. 150(1):25-32.

Somogyi, L., Z. Lasić, S. Vukicević and H. Banfić. 1994. Collagen type IV stimulates an increase in intracellular $\mathrm{Ca}^{2+}$ in pancreatic acinar cells via activation of phospholipase C. Biochem. J. 299(Pt 3):603-611.

Song, G., K. A. Dunlap, J. Kim, D. W. Bailey, T. E. Spencer, R. C. Burghardt, G. F. Wagner, G. A. Johnson and F. W. Bazer. 2009. Stanniocalcin 1 is a luminal epithelial marker for implantation in pigs regulated by progesterone and estradiol. Endocrinology 150(2):936-945.

Tatsumi, K., T. Higuchi, H. Fujiwara, T. Nakayama, K. Itoh, T. Mori, S. Fujii and J. Fujita. 1999. Expression of calcium binding protein D-9k messenger RNA in the mouse uterine endometrium during implantation. Mol. Hum. Reprod. 5(2):153-161.

Tinel, H., H. W. Denker and M. Thie. 2000. Calcium influx in human uterine epithelial RL95-2 cells triggers adhesiveness for trophoblast-like cells. Model studies on signalling events during embryo implantation. Mol. Hum. Reprod. 6(12):11191130.

Tuo, W., J. P. Harney and F. W. Bazer. 1996. Developmentally regulated expression of interleukin-1 beta by peri-implantation conceptuses in swine. J. Reprod. Immunol. 31(3):185-198.

Warembourg, M., C. Perret and M. Thomasset. 1987. Analysis and 
in situ detection of cholecalcin messenger RNA (9000 Mr Yang, H., K. C. Choi, S. H. Hyun and E. B. Jeung. 2011. $\mathrm{CaBP}$ ) in the uterus of the pregnant rat. Cell. Tissue. Res. 247(1):51-57.

White, F. J., J. W. Ross, M. M. Joyce, R. D. Geisert, R. C. Burghardt and G. A. Johnson. 2005. Steroid regulation of cell specific secreted phosphoprotein 1 (osteopontin) expression in the pregnant porcine uterus. Biol. Reprod. 73(6):1294-1301. Coexpression and estrogen-mediated regulation of TRPV6 and PMCA1 in the human endometrium during the menstrual cycle. Mol. Reprod. Dev. 78(4):274-282. 